\section{Hot Water Treatment and Pre-processing Storage Reduce Browning Development in Fresh-cut Potato Slices}

\author{
Pavlos Tsouvaltzis ${ }^{1,2}$, Angelos Deltsidis, and Jeffrey K. Brecht \\ Horticultural Sciences Department, University of Florida, Gainesville, FL \\ 32611-0690
}

Additional index words. minimally processed, discoloration, heat treatment, pre-processing, color, phenolic, polyphenoloxidase, PPO

\begin{abstract}
Enzymatic browning is a serious quality limitation for fresh-cut potato (Solanum tuberosum L.) that has been successfully controlled by heat treatment in other commodities. The use of brief heat treatments with $55^{\circ} \mathrm{C}$ water (HW) applied to 'Russet Burbank' tubers for 10, 20, 30, or 40 min before cutting was evaluated for potential implementation to control tissue browning. After heat treatment, tubers were held at $20{ }^{\circ} \mathrm{C}$ for 0 or 1 day before peeling and slicing. Control tubers were not previously immersed in hot water. All slices were placed in perforated plastic bags and stored at $5^{\circ} \mathrm{C}$ for 6 days. Exposure to $\mathrm{HW}$ for 30 or $40 \mathrm{~min}$ caused severe heat injury. Browning developed in all treatments as indicated by color measurements and discoloration scores (index of extent of discolored area on the slice surface) during storage. Hot water treatment for $10 \mathrm{~min}$ best reduced browning, but only when treated tubers were stored intact for 1 day at $20{ }^{\circ} \mathrm{C}$ before cutting, as indicated by discoloration scores and changes in $L^{*}, a^{*}$, and $H^{o}$ values, which were significantly different from either the control or the other HW treatments. Generally, the severe browning that developed in control slices during storage was associated with significant increases of $25 \%$ and $71 \%$ in phenolic content and antioxidant capacity, respectively. On the other hand, phenolic synthesis increased by only $6.25 \%$ to $13.2 \%$ in HW-treated slices during storage and polyphenoloxidase (PPO) activity was $24 \%$ to $31 \%$ lower compared with the activity before storage. Immersing potato tubers in $55^{\circ} \mathrm{C}$ water for 10 to $20 \mathrm{~min}$ followed by storage at $20^{\circ} \mathrm{C}$ for 1 day before processing reduced but did not prevent browning of peeled slices in terms of color changes and discoloration score. There was no significant correlation between browning and phenolic content or PPO activity.
\end{abstract}

The main quality defect in fresh-cut potato is enzymatic browning that develops on the cut surfaces of the tissue. Peeling and slicing of tubers cause cellular disruption leading to decompartmentalization of substrates and enzymes (Brecht et al., 2004). This disruption liberates PPO enzyme from mitochondria, allowing it to contact phenolic substrates in the vacuole and oxidize them to quinones, which then polymerize to dark pigments (Friedman, 1997; Martinez and Whitaker, 1995). 'Russet Burbank', which is the major commercial potato cultivar in the United States, is very susceptible to enzymatic browning compared with other cultivars (Coetzer et al., 2001) as a result of its high phenolic content and PPO activity (Sapers et al., 1989).

Therefore, in contrast to products with low phenolic content for which inactivation of phenylalanine ammonia-lyase (PAL) en-

\footnotetext{
Received for publication 22 Mar. 2011. Accepted for publication 25 June 2011.

Critical reading of the manuscript by A.S. Siomos is gratefully acknowledged.

${ }^{1}$ Current address: Department of Horticulture, Aristotle University of Thessaloniki, 54124, Thessaloniki, Greece.

${ }^{2}$ To whom reprint requests should be addressed; e-mailptsouv@agro.auth.gr.
}

zyme is the most effective way to minimize enzymatic browning (Saltveit, 2000), for products that are rich in phenols such as fresh-cut potatoes, it is necessary to inhibit PPO to prevent the oxidation of pre-existing phenols and their subsequent transformation into melanins. Various treatments have been applied to fresh-cut potato for reducing browning such as the use of antibrowning compounds like sulfites, L-cysteine, ascorbic acid, and/or citric acid (Rocculi et al., 2007; Sapers and Miller, 1995), storage under controlled atmosphere conditions (Angós et al., 2008), modified atmosphere or vacuum packaging (Beltrán et al., 2005), or combinations of these (Limbo and Piergiovanni, 2006; Ma et al., 2010). Until now, sulfites have proven to be consistently the most effective browning inhibitors, but their use for this purpose is controversial as a result of the risk of adverse health effects. It is commonly accepted that alternative technologies for the prevention of enzymatic browning need to be developed that will be effective and safe (Coetzer et al., 2001).

Heat treatments have been shown to prevent the wound-induced synthesis of phenols by inhibiting PAL activity and, thus, reducing browning development in fresh-cut vegetables such as celery (Viña and Chaves, 2008) and lettuce (Loaiza-Velarde and Saltveit, 2001). It is questionable, however, whether heat treat- ments can reduce enzymatic browning on tissues such as potato, in which the phenol content is already high before wounding. Sapers and Miller (1995) inhibited discoloration of peeled potatoes during storage for $14 \mathrm{~d}$ at $4{ }^{\circ} \mathrm{C}$ by using a double treatment, ascorbic/ citric acid solutions plus heat followed by dipping in a solution containing ascorbic and citric acids plus sodium acid pyrophosphate. Furthermore, the use of a heated onion extract, applied either by spraying or immersion of slices, exhibited a marked inhibitory effect on potato PPO and, indeed, this inhibitory effect was dependent on the heating temperature (Lee et al., 2002). However, the individual role of heat treatment application has not been studied yet on fresh-cut potato and particularly the effect it has on enzymatic browning during storage as well as on phenolic accumulation and oxidation by PPO.

According to Martinez and Whitaker (1995), heat inactivation of PPO is feasible by applying temperatures of greater than $50{ }^{\circ} \mathrm{C}$, but no further details are cited. According to Koukounaras et al. (2008), compared with an unheated control, dipping peaches in hot water at $50{ }^{\circ} \mathrm{C}$ for $10 \mathrm{~min}$ before slicing had no effect on PPO activity during storage of fresh-cut peaches in modified atmosphere packaging (MAP) with $2 \%$ to $2.5 \% \mathrm{CO}_{2}$ at $5{ }^{\circ} \mathrm{C}$ for $6 \mathrm{~d}$. Inhibition of PPO was achieved by heating crude enzyme extracts from apples using high temperatures (greater than $68{ }^{\circ} \mathrm{C}$ ) (Yemenicioğlu et al., 1997) or by blanching potatoes in boiling saline solutions (Severini et al., 2003). However, kinetic characteristics of the enzyme in whole apples heated at the tested conditions might differ from those in vitro and additionally blanching temperatures cannot be applied in minimal processing of horticultural products. Indeed, immersion of potatoes at water bath temperatures of $60^{\circ} \mathrm{C}$ or higher resulted in tuber surface blackening and rapid decay (Ranganna et al., 1998). In studies aiming to prevent sprouting of potatoes during storage, the latter authors demonstrated that the tubers can tolerate HW treatments at $57.5^{\circ} \mathrm{C}$ for 20 to $30 \mathrm{~min}$ and be safely stored for 12 weeks at either 8 or $18{ }^{\circ} \mathrm{C}$ without suffering from heat damage, whereas Kyriacou et al. (2008) reported that tuber tolerance at the same temperature is limited to $20 \mathrm{~min}$. It would be interesting to investigate whether less severe heat treatments could reduce the accumulation of phenolics in stored fresh-cut potato slices as well as their oxidation resulting from the activity of PPO.

It has also been shown that the duration between heat treatment and processing also has a significant effect on enzymatic browning development during storage of fresh-cut products. Particularly, the beneficial effect of heat treatment of peach (Koukounaras et al., 2008) and lettuce (Loaiza-Velarde and Saltveit, 2001) on browning development on the fresh-cut products was further enhanced when the treatment was applied 4 or $6 \mathrm{~h}$, respectively, before processing, indicating that a pre-processing storage interval can significantly affect the success of heat treatment. 
The objective of this study was primarily to evaluate the efficacy of heat treatment in preventing enzymatic browning on fresh-cut potatoes during storage and additionally to examine whether storage delay between heat treatment and processing affects browning development on peeled slices.

\section{Materials and Methods}

Plant material and treatments. U.S. No 1 grade 'Russet Burbank' potato tubers grown in Idaho and stored for $\approx 1$ to 2 months at $7^{\circ} \mathrm{C}$ and $95 \%$ relative humidity were ordered from a local supermarket in Gainesville, FL, and obtained immediately on their delivery from the supermarket distribution center. After being transferred to the Postharvest Facilities at the University of Florida and holding overnight at $20^{\circ} \mathrm{C}$, the potatoes were sorted to remove damaged tubers and were then randomized.

Tubers of uniform size $(460 \pm 60 \mathrm{~g})$ were immersed in $55^{\circ} \mathrm{C}$ water for $0,10,20,30$, or $40 \mathrm{~min}$ (10 tubers per treatment). The hot water treatment system used (Model HWH-2; Gaffney Eng., Gainesville, FL) is a modified version of the apparatus described by Sharp (1989). Immediately after HW treatment, the tubers were cooled by immersion in $8{ }^{\circ} \mathrm{C}$ water for $10 \mathrm{~min}$, dried in front of fans for $\approx 1 \mathrm{~h}$, and placed in a refrigerated storage room at $20{ }^{\circ} \mathrm{C}$ for 0 or $24 \mathrm{~h}$ before being processed (peeled and sliced). Preliminary experiments with 50 and $55{ }^{\circ} \mathrm{C}$ hot water treatments and pre-processing delays at $20^{\circ} \mathrm{C}$ for up to $8 \mathrm{~h}$ were performed using 'Russet Burbank' and 'Russet Norkotah' potatoes that were sourced and treated as described previously.

Tubers were hand-peeled with a potato peeler and cut with a sharp knife perpendicular to the long axis of each tuber into $1-\mathrm{cm}$ thick slices. The seven innermost slices from each tuber were halved; thus, two pieces were obtained from each slice. Pieces were rinsed twice with deionized water for $30 \mathrm{~s}$ each. Moisture on the surface of the pieces was removed by blotting with paper towels, the color was measured, browning was evaluated, then the pieces were placed in plastic bags that had previously been punctured twice with a $9-\mathrm{mm}$ cork borer, stored in a refrigerated storage room at $5{ }^{\circ} \mathrm{C}$ for 0 or $6 \mathrm{~d}$, and were frozen at $-30{ }^{\circ} \mathrm{C}$ before chemical determinations. Four replications were used for each treatment and each replication consisted of 14 pieces.

Color evaluations. Color changes were quantified in the $L^{*} a * b^{*}$ color space using a Minolta colorimeter (Model CR-200b; Minolta Corp., Ramsey, NJ) equipped with an 8-mm diameter measuring head. Color measurements were made at the most discolored area on each one of 14 pieces. Hue angle $\left[H^{\circ}=\tan ^{-1}\left(b^{*} / a^{*}\right)\right.$ when $a^{*}>0$ or $H^{\circ}=180+\tan ^{-1}\left(b^{*} / a^{*}\right)$ when $\left.a^{*}<0\right]$ was calculated from $a^{*}$ and $b^{*}$ values. $L^{*}$ refers to the lightness, ranging from $0=$ black to $100=$ white, and $H^{\circ}$ is defined as an angle on a color wheel, with red-purple at $0^{\circ}$, yellow at $90^{\circ}$, bluish green at $180^{\circ}$, and blue at $270^{\circ}$. In the results, to compare samples with different initial color, $\% \Delta L^{*}=\left(L_{\text {day } 6}^{*}-L_{\text {day } 0}^{*}\right) /$
$\left|L_{\text {day } 0}^{*}\right| \times 100, \% \Delta a^{*}=\left(a_{\text {day } 6}^{*}-a_{\text {day } 0}^{*}\right) /\left|a_{\text {day } 0}^{*}\right| \times$ $100, \% \Delta H^{o}=\left(H_{\mathrm{day} 6}^{o}-H_{\mathrm{day} 0}^{o}\right) /\left|H_{\mathrm{day} 0}^{o}\right| \times 100$ were calculated as percent of the initial value, and $\Delta \mathrm{E}$ was also calculated as $\left[\left(L_{\mathrm{day} 6}^{*}\right.\right.$ $\left.\left.L_{\text {day } 0}^{*}\right)^{2}+\left(a_{\text {day } 6}^{*}-a_{\text {day } 0}^{*}\right)^{2}+\left(b_{\text {day } 6}^{*}-b_{\text {day } 0}^{*}\right)^{2}\right]^{1 / 2}$

Browning evaluation. Brown discoloration was evaluated subjectively on a scale of 1 to 5 based on the extent of discolored area (DA) on each of 14 pieces, in which $1=$ none $(0 \% \mathrm{DA})$, $2=$ slight $(1 \%$ to $5 \% \mathrm{DA}), 3=$ moderate $(6 \%$ to $50 \%$ DA), $4=$ moderately severe $(51 \%$ to $90 \% \mathrm{DA}$ ), and $5=$ very severe (greater than $90 \%$ DA).

Chemical determinations. Frozen tuber pieces were homogenized and the resulting tissue slurries were used for the determination of PPO activity as well as total phenol content and antioxidant capacity.

Polyphenoloxidase activity. Tissue slurry aliquots of $5 \mathrm{~g}$ were rehomogenized in $30 \mathrm{~mL}$ of $0.1 \mathrm{~m}$ sodium phosphate buffer, $\mathrm{pH}$ 6.6, together with $0.5 \mathrm{~g}$ of polyvinylpyrrolidone and centrifuged at 17,600 $g_{n}$ for $20 \mathrm{~min}$. The supernatant was filtered through Whatman No. 4 filter paper and the filtrate was used for PPO activity measured by determining the absorbance increase at $420 \mathrm{~nm}$ over a period of $1 \mathrm{~min}$ at $25^{\circ} \mathrm{C}$. The reaction mixture contained $1 \mathrm{~mL}$ of extract, $1 \mathrm{~mL}$ of phosphate buffer, and $1 \mathrm{~mL}$ of $0.2 \mathrm{~m}$ catechol. The results were expressed as units of enzyme activity per $1 \mathrm{~g}$ fresh weight (units/g FW). One unit of enzyme activity was defined as the amount of the enzyme that caused a 0.01 change in absorbance in the first $15 \mathrm{~s}$ after addition of catechol to the reaction mixture.

Total phenol content and antioxidant capacity. Five grams of the blended material were homogenized in $25 \mathrm{~mL}$ of $2 \mathrm{~mm}$ sodium fluoride in $80 \%$ methanol for $2 \mathrm{~min}$, centrifuged at $4{ }^{\circ} \mathrm{C}$ and 17,600 $g_{n}$ for $20 \mathrm{~min}$, and filtered through Whatman No 4 paper. The same extraction was conducted for both total phenols and antioxidant capacity. Total phenols were determined according to the method of Singleton and Rossi (1965) and was expressed as micrograms of gallic acid equivalents per $1 \mathrm{~g}$ of fresh weight ( $\mu \mathrm{g} \cdot \mathrm{g}^{-1} \mathrm{GAE}$ FW). Antioxidant capacity assay was performed following the procedure described by Brand-Williams et al. (1995) with minor modifications. The extract $(200 \mu \mathrm{L})$ was pipetted into $1.8 \mathrm{~mL}$ of $0.1 \mathrm{~mm}$ methanolic 1,1 diphenyl-2-picryl-hydrazyl (DPPH) solution to initiate the reaction. The absorbance was read after $15 \mathrm{~min}$ at $517 \mathrm{~nm}$. Ascorbic acid was used as a standard and the DPPH radical scavenging activity was expressed as milligrams of ascorbic acid equivalents antioxidant capacity (AEAC) per $100 \mathrm{~g} \mathrm{FW}$ (mg. $100 \mathrm{~g}^{-1}$ AEAC FW).

Statistical analysis. A completely randomized design was used. Analysis of variance was performed to evaluate the effect of HW treatment, pre-processing delay, and storage. Means were separated by Duncan's multiple range test at the 0.05 level.

\section{Results and Discussion}

Severe heat injury developed on slices from tubers treated for 30 or $40 \mathrm{~min}$ at $55^{\circ} \mathrm{C}$, and therefore they were discarded and not included in the study, although Ranganna et al. (1998) reported that cv. Superior potato tubers withstood a $\mathrm{HW}$ treatment of $57.5^{\circ} \mathrm{C}$ for up to 30 min without damaging the tissue. According to Lurie (1998), many fruits and vegetables tolerate exposure to water temperatures of 50 to $60{ }^{\circ} \mathrm{C}$ for up to $10 \mathrm{~min}$. On the other hand, Kyriacou et al. (2008) reported that for 'Hermes' potato tubers, 20-min exposure time was the longest safe limit for HW treatment at $57.5^{\circ} \mathrm{C}$ and $25 \mathrm{~min}$ for treatment at $55^{\circ} \mathrm{C}$, suggesting the possibility that physiological age, cultivar, and pre-processing storage conditions significantly affect thermotolerance in potato tuber.

Increases in $a^{*}$ and decreases in $L^{*}$ and $H^{o}$ values are indicative of browning on potato (Ma et al., 2010; Sapers and Miller, 1995), whereas according to Cantos et al. (2002), the best indicator of browning appearance in fresh-cut potato strips is lightness $\left(L^{*}\right)$. A $\Delta \mathrm{E}$ above 3 has been reported to represent browning that is perceivable to humans (Limbo and Piergiovanni, 2006). Regression analysis showed that all color changes $\left(\% \Delta L^{*}, \% \Delta a^{*}, \Delta H^{o}\right.$, and $\Delta \mathrm{E})$ correlated well with each other $(R>$ $0.984, P \leq 0.0026$ ) (Table 1$)$. A good correlation between $L^{*}$ and $a^{*}$ on peeled potatoes has been also reported by Thybo et al. (2006). The parameters $b^{*}$ and chroma $\left(C^{*}\right)$ obtained from the raw data did not exhibit any treatment effects.

Color changes were significantly affected by HW treatment duration, pre-processing duration as well as by their interaction (Table 2). However, most of the total variance $(52 \%$, $91 \%, 57 \%$, and $52 \%$ ) was accounted for by differences between pre-processing duration for $\% \Delta L^{*}, \% \Delta a^{*}, \% \Delta H^{o}$, and $\Delta \mathrm{E}$, respectively. After $6 \mathrm{~d}$ storage at $5{ }^{\circ} \mathrm{C}, L^{*}$ and $H^{\circ}$ in non-HW-treated (control) potato slices decreased by $21 \%$ and $15 \%$, respectively, whereas $a^{*}$ and $\Delta \mathrm{E}$ increased by $204 \%$ and $15 \%$, respectively (Table 3 ). Slices from tubers treated with HW and processed immediately on the completion of the treatment exhibited color changes that were similar to the control irrespective of the duration of the treatment.

Storage of HW-treated tubers for $1 \mathrm{~d}$ at $20{ }^{\circ} \mathrm{C}$ before peeling and slicing resulted in significantly smaller color changes after storage than control slices or those from tubers processed immediately after HW treatment with no difference between 10- and 20-min HW treatment durations (Table 3). Particularly, $L^{*}$ and $H^{o}$ decreased by $6 \%$ to $12 \%$ and $7 \%$ to $9 \%$, respectively, whereas $a^{*}$ and $\Delta \mathrm{E}$ increased by $71 \%$ to $108 \%$ and $6 \%$ to $9 \%$, respectively, in slices obtained from tubers treated for 10 or $20 \mathrm{~min}$ and stored for $1 \mathrm{~d}$ at $20{ }^{\circ} \mathrm{C}$ before being peeled and sliced. Sapers and Miller (1995) reported that minimal color changes occurred in Russet and round-white type abrasion-peeled potatoes that had been dipped for $15 \mathrm{~min}$ in a heated $\left(55^{\circ} \mathrm{C}\right)$ acidic ( $1 \%$ ascorbic acid $+2 \%$ citric acid) solution followed by dipping in a browning inhibitor solution (4\% ascorbic acid $+1 \%$ sodium acid pyrophosphate $+0.2 \% \mathrm{CaCl}_{2}$ ) before storage for 2 weeks at $4{ }^{\circ} \mathrm{C}$. Indeed, $\Delta L^{*}$ values 
Table 1. Correlation coefficients $(\mathrm{R})$ and probability $(P)$ for color changes $\left(\% \Delta L^{*}, \% \Delta a^{*}, \% \Delta H^{o}\right.$, and $\left.\Delta \mathrm{E}\right)$, total soluble phenolics, PPO activity, antioxidant capacity, and discoloration score.

\begin{tabular}{|c|c|c|c|c|c|c|c|c|c|c|c|c|c|c|c|c|}
\hline & \multicolumn{2}{|c|}{$\% \Delta L^{*}$} & \multicolumn{2}{|c|}{$\% \Delta \mathrm{a}^{*}$} & \multicolumn{2}{|c|}{$\% \Delta H^{\circ}$} & \multicolumn{2}{|c|}{$\Delta \mathrm{E}$} & \multicolumn{2}{|c|}{ Total soluble phenolics } & \multicolumn{2}{|c|}{ PPO activity } & \multicolumn{2}{|c|}{ Antioxidant capacity } & \multicolumn{2}{|c|}{ Discoloration score } \\
\hline & $\mathrm{R}$ & $P$ & $\mathrm{R}$ & $P$ & $\mathrm{R}$ & $P$ & $\mathrm{R}$ & $P$ & $\mathrm{R}$ & $P$ & $\mathrm{R}$ & $P$ & $\mathrm{R}$ & $P$ & $\mathrm{R}$ & $P$ \\
\hline$\% \Delta a *$ & & & & & -1.00 & 0.001 & 0.99 & 0.001 & 0.34 & 0.580 & 0.35 & 0.569 & 0.43 & 0.468 & 0.91 & 0.035 \\
\hline$\% \Delta H^{\circ}$ & & & & & & & -0.99 & 0.002 & -0.25 & 0.686 & -0.25 & 0.680 & -0.35 & 0.562 & -0.91 & 0.031 \\
\hline $\begin{array}{c}\text { Total soluble } \\
\text { phenolics }\end{array}$ & & & & & & & & & & & 0.78 & 0.123 & 0.97 & 0.005 & 0.35 & 0.559 \\
\hline PPO activity & & & & & & & & & & & & & 0.80 & 0.103 & 0.26 & 0.672 \\
\hline $\begin{array}{l}\text { Discoloration } \\
\text { score }\end{array}$ & & & & & & & & & & & & & & & & \\
\hline
\end{tabular}

Table 2. Analysis of variance for color changes $\left(\% \Delta L^{*}, \% \Delta a^{*}, \% \Delta H^{o}\right.$, and $\left.\Delta \mathrm{E}\right)$ of fresh-cut potato slices after storage in perforated plastic bags at $5{ }^{\circ} \mathrm{C}$ for $6 \mathrm{~d} .{ }^{z}$

\begin{tabular}{|c|c|c|c|c|c|c|c|c|}
\hline \multirow[b]{2}{*}{ Source of variance } & \multicolumn{2}{|c|}{$\% \Delta L^{*}$} & \multicolumn{2}{|c|}{$\% \Delta a^{*}$} & \multicolumn{2}{|c|}{$\% \Delta H^{o}$} & \multicolumn{2}{|c|}{$\Delta \mathrm{E}^{\mathrm{y}}$} \\
\hline & Mean squares & Percent of $\mathrm{TV}^{\mathrm{x}}$ & Mean squares & Percent of TV & Mean squares & Percent of TV & Mean squares & Percent of TV \\
\hline (B) HWT duration ${ }^{v}$ & $195.4 * * *$ & 30.13 & $16,425 * * *$ & 5.55 & $52.2 * * *$ & 22.49 & $79.5 * * *$ & 30.41 \\
\hline
\end{tabular}

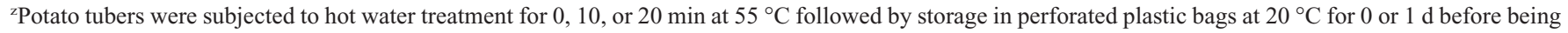
peeled and sliced.

${ }^{\mathrm{y}} \Delta \mathrm{E}=\left(\Delta L^{* 2}+\Delta a^{* 2}+\Delta b^{* 2}\right)^{1 / 2}$

${ }^{\mathrm{x}} \mathrm{TV}=$ total variance.

${ }^{\mathrm{w}} 0$ or $1 \mathrm{~d}$ storage at $20^{\circ} \mathrm{C}$.

${ }^{\mathrm{v}} 0,10$, or $20 \mathrm{~min}$ at $55^{\circ} \mathrm{C}$.

$*, * *, * * *$ Significant effect at $P \leq 0.05,0.01$, or 0.001 , respectively.

Table 3. Color changes ( $\% \Delta L^{*}, \% \Delta a^{*}, \% \Delta H^{o}$, and $\left.\Delta \mathrm{E}\right)$ of fresh-cut potato slices after storage in perforated plastic bags at $5^{\circ} \mathrm{C}$ for $6 \mathrm{~d} .^{\mathrm{z}}$

\begin{tabular}{lccccc}
\hline $\begin{array}{l}\text { Hot water treatment } \\
\text { duration (min) }\end{array}$ & $\begin{array}{l}\text { Pre-processing } \\
\text { duration (days) }\end{array}$ & $\% \Delta L^{*}$ & $\% \Delta a^{*}$ & $\% \Delta H^{o}$ & $\Delta \mathrm{E}^{\mathrm{y}}$ \\
\hline 0 & 0 & $-21.21^{\mathrm{x}} \mathrm{b}^{\mathrm{w}}$ & $203.5 \mathrm{a}$ & $-14.96 \mathrm{~b}$ & $15.05 \mathrm{a}$ \\
& 0 & $-18.52 \mathrm{~b}$ & $185.4 \mathrm{a}$ & $-14.72 \mathrm{~b}$ & $13.32 \mathrm{a}$ \\
10 & 0 & $-19.86 \mathrm{~b}$ & $172.9 \mathrm{a}$ & $-13.75 \mathrm{~b}$ & $13.96 \mathrm{a}$ \\
20 & & $-6.35 \mathrm{a}$ & $70.5 \mathrm{~b}$ & $-6.54 \mathrm{a}$ & $5.68 \mathrm{~b}$ \\
& 1 & $-11.86 \mathrm{a}$ & $107.8 \mathrm{~b}$ & $-9.33 \mathrm{a}$ & $8.88 \mathrm{~b}$ \\
\hline
\end{tabular}

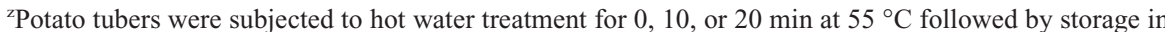
perforated plastic bags at $20^{\circ} \mathrm{C}$ for 0 or $1 \mathrm{~d}$ before being peeled and sliced.

${ }^{\mathrm{y}} \Delta \mathrm{E}=\left(\Delta L^{* 2}+\Delta a^{* 2}+\Delta b^{* 2}\right)^{1 / 2}$.

${ }^{\mathrm{x}}$ Each value is the mean of four replications.

wMeans within each column with the same letter are not significally different according to Duncan's multiple range test $(P<0.05)$

clearly showed that the $55{ }^{\circ} \mathrm{C} / 15$-min treatment in the heated solution followed by the browning inhibitor dip was more effective than the dip alone, although the individual effect of heat treatment was not evaluated.

Browning evaluation showed that discoloration was mainly affected by storage (by $99 \%$ ) and less by HW treatment and preprocessing duration (Table 4). Browning was assessed as moderately severe to severe in almost all slices (4.1 to 4.5 discoloration scores), whereas it was only moderate to moderately severe $(3.3$ score) in slices from tubers that were heated in water at $55^{\circ} \mathrm{C}$ for $10 \mathrm{~min}$ and stored intact for $1 \mathrm{~d}$ at $20{ }^{\circ} \mathrm{C}$ before being processed (Table 5). Slices produced by tubers that were $\mathrm{HW}$ treated at $55^{\circ} \mathrm{C}$ for 20 min were scored higher, presumably as a result of a slight heat injury caused by the prolonged immersion time. Discoloration scores correlated well $(R>0.905, P<0.035)$ with all color changes $\left(\% \Delta L^{*}, \% \Delta a^{*}, \% \Delta H^{o}\right.$, and $\left.\Delta \mathrm{E}\right)$ (Table 1), contrary to a report on minimally processed apples in which the browning index correlated better with $a^{*}$ than $L^{*}$ values (Rocha and Morais, 2002).

Total phenol content, antioxidant capacity, and PPO activity were mainly affected by storage (by $74 \%, 77 \%$, and $97 \%$ ) (Table 4 ). Particularly, phenol content increased significantly during $6 \mathrm{~d}$ of storage at $5^{\circ} \mathrm{C}$ in slices from control tubers $\left(0.40 \mu \mathrm{g} \cdot \mathrm{g}^{-1} \mathrm{GAE} \mathrm{FW}\right)$ compared with initial phenol content before storage (0.32 $\mu \mathrm{g} \cdot \mathrm{g}^{-1}$ GAE FW) (Table 5). Tudela et al. (2002) reported a remarkable increase in the chlorogenic acid content of freshcut 'Liseta', 'Spunta', 'Agria', 'Monalisa', and 'Cara' potato strips after $6 \mathrm{~d}$ of storage at $4{ }^{\circ} \mathrm{C}$, similar to the report by Cantos et al. (2002) for the same cultivars. Chlorogenic acid constitutes up to $90 \%$ of the total phenolic content of potato tubers with $50 \%$ of that content located in the potato peel and adjoining tissues, whereas the remainder decreases in concentration from the outside toward the center of potato tubers (Friedman, 1997). Slices from potatoes dipped in HW irrespective of treatment or pre-processing duration had a phenol content of 0.34 to $0.36 \mu \mathrm{g} \cdot \mathrm{g}^{-1} \mathrm{GAE}$ $\mathrm{FW}$, which was not significantly different from the control either before or after storage (Table 5 ). There was no correlation between the total phenolic content and either discoloration score or color changes (Table 1), in agreement with Rocha and Morais (2002). Although the accumulation of wound-induced phenolic compounds can increase the velocity of oxidative reactions catalyzed by enzymes such as PPO, giving rise to melanins (enzymatic browning) (Tudela et al., 2002), the initially high content of phenols (mainly chlorogenic acid) in potato tuber is more than sufficient to support browning so that phenolic accumulation is not the rate-limiting step in browning development (Cantos et al., 2002).

Antioxidant capacity significantly increased during storage in control slices $\left(16.5 \mathrm{mg} \cdot 100 \mathrm{~g}^{-1}\right.$ AEAC FW) compared with the initial levels before storage $\left(9.6 \mathrm{mg} \cdot 100 \mathrm{~g}^{-1}\right.$ AEAC FW) (Table 5). Slices from tubers that were HWtreated for either 10 or $20 \mathrm{~min}$ and processed the same day or slices from tubers that were HWtreated for $10 \mathrm{~min}$ and stored at $20^{\circ} \mathrm{C}$ for $1 \mathrm{~d}$ before being processed had lower antioxidant capacity ( 11.7 to $12.0 \mathrm{mg} \cdot 100 \mathrm{~g}^{-1}$ AEAC FW), which was not significantly different from the level before storage. The changes in antioxidant capacity during storage coincided with the changes in phenol content and this result is also confirmed by the strong correlation $(R=0.974$, $P<0.005$ ) between these two parameters (Table 
Table 4. Analysis of variance for discoloration score, phenolics content, antioxidant capacity, and polyphenoloxidase (PPO) activity of fresh-cut potato slices after storage in perforated plastic bags at $5{ }^{\circ} \mathrm{C}$ for $6 \mathrm{~d} .^{\mathrm{z}}$

\begin{tabular}{|c|c|c|c|c|c|c|c|c|}
\hline & \multicolumn{2}{|c|}{ Discoloration score ${ }^{y}$} & \multicolumn{2}{|c|}{ Total soluble phenolics } & \multicolumn{2}{|c|}{ Antioxidant capacity } & \multicolumn{2}{|c|}{ PPO activity } \\
\hline & Mean squares & Percent of $\mathrm{TV}^{\mathrm{x}}$ & Mean squares & Percent of TV & Mean squares & Percent of TV & Mean squares & Percent of TV \\
\hline (A) Pre-processing duration ${ }^{\mathrm{w}}$ & $0.04 * *$ & 0.25 & 0.00025 & 0.74 & 0.80 & 0.31 & 0.02 & 0.02 \\
\hline (B) HWT duration ${ }^{v}$ & $0.04 * * *$ & 0.25 & 0.00325 & 9.58 & $25.22 * *$ & 9.91 & 2.88 & 2.72 \\
\hline $\mathrm{A} \times \mathrm{B}$ & $0.02 * *$ & 0.12 & 0.00013 & 0.37 & 0.89 & 0.35 & 0.38 & 0.36 \\
\hline (C) Storage ${ }^{u}$ & $15.89 * * *$ & 98.73 & $0.02506^{* * *}$ & 73.85 & $196.22 * * *$ & 77.07 & $97.21 * * *$ & 91.65 \\
\hline $\mathrm{A} \times \mathrm{C}$ & $0.04 * *$ & 0.25 & 0.00025 & 0.74 & 0.80 & 0.31 & 0.02 & 0.02 \\
\hline $\mathrm{B} \times \mathrm{C}$ & $0.04 * * *$ & 0.25 & 0.00325 & 9.58 & $25.22 * *$ & 9.91 & 2.88 & 2.72 \\
\hline $\mathrm{A} \times \mathrm{B} \times \mathrm{C}$ & $0.02 * *$ & 0.12 & 0.00013 & 0.37 & 0.89 & 0.35 & 0.38 & 0.36 \\
\hline Error & 0.004 & 0.02 & 0.00163 & 4.79 & 4.57 & 1.79 & 2.3 & 2.17 \\
\hline
\end{tabular}

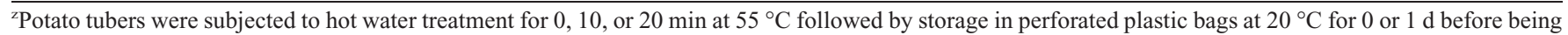
peeled and sliced.

${ }^{\mathrm{y}} 1=0 \%, 2=1 \%$ to $5 \%, 3=6 \%$ to $50 \%, 4=51 \%$ to $90 \%, 5=91 \%$ to $100 \%$ surface discoloration.

xTotal variance.

${ }^{\mathrm{w}} 0$ or $1 \mathrm{~d}$ at $20^{\circ} \mathrm{C}$.

${ }^{\mathrm{v}} 0,10$, or $20 \mathrm{~min}$ at $55^{\circ} \mathrm{C}$.

" 0 or $6 \mathrm{~d}$ at $5^{\circ} \mathrm{C}$.

$* *, * * *$ Significant effect at $P \leq 0.01$, or 0.001 , respectively.

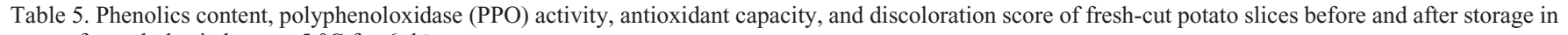
perforated plastic bags at $5{ }^{\circ} \mathrm{C}$ for $6 \mathrm{~d} .^{z}$

\begin{tabular}{|c|c|c|c|c|c|c|}
\hline $\begin{array}{l}\text { Hot water treatment } \\
\text { duration }(\mathrm{min})\end{array}$ & $\begin{array}{l}\text { Pre-processing } \\
\text { duration (days) }\end{array}$ & Storage (days) & $\begin{array}{l}\text { Total soluble phenolics } \\
\quad\left(\mu g \cdot g^{-1} \text { GAE FW }\right)\end{array}$ & $\begin{array}{l}\text { PPO activity } \\
\left(\mathrm{U} \cdot \mathrm{g}^{-1} \mathrm{FW}\right)^{\mathrm{u}}\end{array}$ & $\begin{array}{c}\text { Antioxidant capacity } \\
\left(\mathrm{mg} \cdot 100 \mathrm{~g}^{-1} \text { AEAC FW) }\right.\end{array}$ & Discoloration score $^{\mathrm{x}}$ \\
\hline 0 & 0 & 0 & $0.317^{\mathrm{w}} \mathrm{b}^{\mathrm{v}}$ & $12.359 \mathrm{a}$ & $9.63 \mathrm{c}$ & $1.00 \mathrm{c}$ \\
\hline 0 & 0 & 6 & $0.395 \mathrm{a}$ & $10.474 \mathrm{ab}$ & $16.51 \mathrm{a}$ & $4.46 \mathrm{a}$ \\
\hline 10 & 0 & 6 & $0.343 \mathrm{ab}$ & $8.509 \mathrm{~b}$ & $11.75 \mathrm{bc}$ & $4.27 \mathrm{a}$ \\
\hline 20 & 0 & 6 & $0.336 \mathrm{ab}$ & $9.423 \mathrm{~b}$ & $11.99 \mathrm{bc}$ & $4.29 \mathrm{a}$ \\
\hline 10 & 1 & 6 & $0.347 \mathrm{ab}$ & $9.250 \mathrm{~b}$ & $11.70 \mathrm{bc}$ & $3.27 \mathrm{~b}$ \\
\hline 20 & 1 & 6 & $0.359 \mathrm{ab}$ & $8.937 \mathrm{~b}$ & $13.59 \mathrm{ab}$ & $4.09 \mathrm{a}$ \\
\hline
\end{tabular}

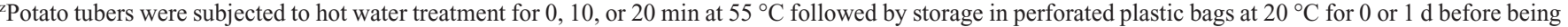
peeled and sliced.

${ }^{\mathrm{y}} 1$ unit $=\Delta$ Absorbance $_{420} / \mathrm{min}$.

${ }^{\mathrm{x}} 1=0 \%, 2=1 \%$ to $5 \%, 3=6 \%$ to $50 \%, 4=51 \%$ to $90 \%, 5=91 \%$ to $100 \%$ surface discoloration.

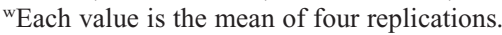

${ }^{\vee}$ Means within each column followed by different letter are not significantly different according to Duncan's multiple range test $(P<0.05)$.

1). Although chemical or enzymatic oxidations have been widely shown to cause a progressive decrease in polyphenol antioxidant properties, polyphenols with an intermediate oxidation state can exhibit higher radical scavenging efficiency than the non-oxidized polyphenols (Nicoli et al., 1999).

Polyphenoloxidase activity of peeled potato slices before storage was $12.40 \mathrm{U} \cdot \mathrm{g}^{-1} \mathrm{FW}$, not significantly different from the enzyme activity of control slices after storage $\left(10.5 \mathrm{U} \cdot \mathrm{g}^{-1}\right.$ $\mathrm{FW}$ (Table 5). PPO activity in slices produced by tubers subjected to HW treatment, however, and processed either the same or the next day was significantly lower $\left(8.51\right.$ or $9.25 \mathrm{U} \cdot \mathrm{g}^{-1}$ FW) activity than of peeled slices before storage. According to Coetzer et al. (2001), it is possible that a trace amount of PPO is all that is needed to produce some visible discoloration in potato tubers. Although there have been many reports of high correlation between enzymatic browning and PPO activity in apple (Rocha and Morais, 2002) or potato (Coetzer et al., 2001; Sapers et al., 1989; Thybo et al., 2006), in this study, there was no correlation between PPO and either color changes or phenol content or antioxidant capacity (Table $1)$; this is in accordance with the results reported by Cantos et al. (2002).

Although oxidation of phenolic compounds by PPO is responsible for undesirable browning development in fresh-cut products, epidemiological studies, together with information on the chemical and biological properties of the various classes of phenolics in foods, suggest that phenolics contribute significantly to the health benefits of fruits and vegetables in the human diet (Tomás-Barberán and Espín, 2001). Therefore, a possible approach to reducing enzymatic browning reactions in potatoes would be to characterize and inactivate the genes coding for PPO (Friedman, 1997). Subsequently, monomeric polyphenol content will increase, which in turn will preserve the beneficial dietary consequences.

The effect of heat treatments on the PPO activity of fresh-cut commodities has been studied only in peach, and no significant effect of fruit dipping at $50{ }^{\circ} \mathrm{C}$ for $10 \mathrm{~min}$ was found during storage (Koukounaras et al., 2008). In all other studies, PPO inhibition was accomplished only by using a range of high temperatures that cannot be implemented in the fresh-cut industry. Indeed, experiments with crude PPO extracts of various apple cultivars showed that activity of apple PPO increased with mild heating $\left(68^{\circ} \mathrm{C}\right.$ for $\left.15 \mathrm{~min}\right)$, reaching a maximum and declining thereafter as heating progressed (Yemenicioğlu et al., 1997). These authors suggested that the observed increase in activity of apple PPO by heating could, in part, be the result of the activation of a latent form of PPO. Blanching potatoes in boiling sodium chloride or calcium chloride plus lactic acid solutions also inactivated PPO in potato (Severini et al., 2003).
Furthermore, treating potato slices for $10 \mathrm{~min}$ with a $100{ }^{\circ} \mathrm{C}$ solution containing onion extract along with catechol substrate exhibited a higher inhibitory effect on potato PPO activity than that of fresh onion extract (Lee et al., 2002). To the best of our knowledge, this is the first study that reports the effect of a mild HW treatment on PPO in fresh-cut potato.

A pre-processing storage period of $1 \mathrm{~d}$ after HWT significantly affected all color parameters (Table 2) as well as discoloration score (Table 4) on the fresh-cut potato slices. Similar effects have been reported for freshcut lettuce (Loaiza-Velarde and Saltveit, 2001) and fresh-cut peach (Koukounaras et al., 2008). Particularly, the maximum effect of heat treatment on browning control of these products occurred when lettuce was HW treated $6 \mathrm{~h}$ before cutting and peach was treated $4 \mathrm{~h}$ before slicing.

According to analysis of variance, no significant effects of the HW treatment or the pre-processing storage on phenol content or PPO activity were observed (Table 4), probably because differences in those compounds at the wounded surfaces were obscured in the total mass of slices that was used in the chemical analyses.

The results of this study confirm that 'Russet Burbank' potato is very susceptible to browning, agreeing with previous conclusions that not all varieties of a particular vegetable can be used to produce prepared vegetables. Indeed, 
the correct choice of variety is particularly important in the case of potato. A study evaluating various potato cultivars (not including 'Russet Burbank') for their suitability to be processed as fresh-cut products revealed that the cultivars that showed less browning incidence and color changes, thus receiving the highest appearance scores during storage at $5{ }^{\circ} \mathrm{C}$, were characterized by low phenol content and PPO activity and high antioxidant capacity (Cabezas-Serrano et al., 2009). The authors concluded that initial composition in terms of phenol content, vitamin C, sugar content, antioxidant capacity, and enzymatic activity partially explains potato suitability to be processed as fresh-cut products.

\section{Conclusion}

Heat treatment alone is not sufficient to inhibit enzymatic browning in fresh-cut potato. Browning, in terms of color changes of peeled slices, was reduced only when HW dipping at $55{ }^{\circ} \mathrm{C}$ for 10 to 20 min was followed by storage at $20^{\circ} \mathrm{C}$ for $1 \mathrm{~d}$ before processing. This is a promising discovery and should therefore be exploited in the future by combining HW treatment and delay before processing with antibrowning compounds applied at lower concentrations or with less stressful atmospheric conditions than those currently being used for MAP of fresh-cut potato.

\section{Literature Cited}

Angós, I., P. Vírseda, and T. Fernández. 2008. Control of respiration and color modification on minimally processed potatoes by means of low and high $\mathrm{O}_{2} / \mathrm{CO}_{2}$ atmospheres. Postharvest Biol. Technol. 48:422-430.

Beltrán, D., M.V. Selma, J.A. Tudela, and M.I. Gil. 2005. Effect of different sanitizers on microbial and sensory quality of fresh-cut potato strips stored under modified atmosphere or vacuum packaging. Postharvest Biol. Technol. 37:3746.

Brand-Williams, W., M.E. Cuvelier, and C. Berset. 1995. Use of a radical method to evaluate antioxidant activity. LWT Food Sci. Technol. 28:25-30.

Brecht, J.K., M.E. Saltveit, S.T. Talcott, K.R. Schneider, K. Felkey, and J.A. Bartz. 2004. Fresh-cut vegetables and fruits. Hort. Rev. 30:185-251.

Cabezas-Serrano, A.B., M.L. Amodio, R. Cornacchia, R. Rinaldi, and G. Colelli. 2009. Suitability of five different potato cultivars (Solanum tuberosum L.) to be processed as fresh-cut products. Postharvest Biol. Technol. 53: 138-144.

Cantos, E., J.A. Tudela, M.I. Gil, and J.C. Espiìn. 2002. Phenolic compounds and related enzymes are not rate-limiting in browning development of fresh-cut potatoes. J. Agr. Food Chem. 50:3015-3023.

Coetzer, C., D. Corsini, S. Love, J. Pavek, and N. Turner. 2001. Control of enzymatic browning in potato (Solanum tuberosum L.) by sense and antisense RNA from tomato polyphenol oxidase. J. Agr. Food Chem. 49:652-657.

Friedman, M. 1997. Chemistry, biochemistry, and dietary role of potato polyphenols. A review. J. Agr. Food Chem. 45:1523-1540.

Koukounaras, A., G. Diamantidis, and E. Sfakiotakis. 2008. The effect of heat treatment on quality retention of fresh-cut peach. Postharvest Biol. Technol. 48:30-36.

Kyriacou, M.C., D. Gerasopoulos, A.S. Siomos, and I.M. Ioannides. 2008. Impact of hot water treatment on sprouting, membrane permeability, sugar content and chip colour of reconditioned potato tubers following long-term cold storage. J. Sci. Food Agr. 88:2682-2687.

Lee, M.K., Y.M. Kim, N.Y. Kim, G.N. Kim, S.H. Kim, K.S. Bang, and I. Park. 2002. Prevention of browning in potato with a heat-treated onion extract. Biosci. Biotechnol. Biochem. 66:856858.

Limbo, S. and L. Piergiovanni. 2006. Shelf life of minimally processed potatoes: Part 1 . Effects of high oxygen partial pressures in combination with ascorbic and citric acids on enzymatic browning. Postharvest Biol. Technol. 39:254 264.

Loaiza-Velarde, J.G. and M.E. Saltveit. 2001. Heat shocks applied either before or after wounding reduce browning of lettuce leaf tissue. J. Amer. Soc. Hort. Sci. 126:227-234.

Lurie, S. 1998. Postharvest heat treatments. Postharvest Biol. Technol. 14:257-269.

Ma, Y., Q. Wang, G. Hong, and M. Cantwell. 2010. Reassessment of treatments to retard browning of fresh-cut Russet potato with emphasis on controlled atmospheres and low concentrations of bisulphite. Intl. J. Food Sci. Technol. 45: 1486-1494.

Martinez, M.V. and J.R. Whitaker. 1995. The biochemistry and control of enzymatic browning. Trends Food Sci. Technol. 6:195-200.

Nicoli, M.C., M. Anese, and M. Parpinel. 1999. Influence of processing on the antioxidant properties of fruit and vegetables. Trends Food Sci. Technol. 10:94-100.

Ranganna, B., G.S.V. Raghavan, and A.C. Kushalappa. 1998. Hot water dipping to enhance storability of potatoes. Postharvest Biol. Technol. 13:215-223.

Rocculi, P., F.G. Galindo, F. Mendoza, L. Wadsö, S. Romani, M.D. Rosa, and I. Sjöholm. 2007. Effects of the application of anti-browning substances on the metabolic activity and sugar composition of fresh-cut potatoes. Postharvest Biol. Technol. 43:151-157.

Rocha, A.M.C.N. and A.M.M.B. Morais. 2002. Polyphenoloxidase activity and total phenolic content as related to browning of minimally processed 'Jonagored' apple. J. Sci. Food Agr. $82: 120-126$

Saltveit, M.E. 2000. Wound induced changes in phenolic metabolism and tissue browning are altered by heat shock. Postharvest Biol. Technol. 21:61-69.

Sapers, G.M., F.W. Douglas, Jr, A. Bilyk, A.F. Hsu, H.W. Dower, L. Garzarella, and M. Kozempel. 1989. Enzymatic browning in Atlantic potatoes and related cultivars. J. Food Sci. 54:362-365.

Sapers, G.M. and R. Miller. 1995. Heated ascorbic/ citric acid solution as browning inhibitor for pre-peeled potatoes. J. Food Sci. 60:762-766, 776.

Severini, C., A. Baiano, T. De Pilli, R. Romaniello, and A. Derossi. 2003. Prevention of enzymatic browning in sliced potatoes by blanching in boiling saline solutions. LWT Food Sci. Technol. 36:657-665.

Sharp, J.L. 1989. Hot water immersion appliance for quarantine treatment research. J. Econ. Entomol. 82:189-192.

Singleton, V.L. and J.A. Rossi. 1965. Colorimetry of total phenolics with phosphomolybdicphosphotungstic acid reagents. Amer. J. Enol. Viticult. 16:144-158.

Thybo, A.K., J. Christiansen, K. Kaack, and M.A. Petersen. 2006. Effect of cultivars, wound healing and storage on sensory quality and chemical components in pre-peeled potatoes. LWT Food Sci. Technol. 39:166-176.

Tomás-Barberán, F.A. and J.C. Espín. 2001. Phenolic compounds and related enzymes as determinants of quality in fruits and vegetables. J. Sci. Food Agr. 81:853-876.

Tudela, J.A., E. Cantos, J.C. Espín, F.A. TomásBarberán, and M.I. Gil. 2002. Induction of antioxidant flavonol biosynthesis in fresh-cut, potatoes. Effect of domestic cooking. J. Agr. Food Chem. 50:5925-5931.

Viña, S.Z. and A.R. Chaves. 2008. Effect of heat treatment and refrigerated storage on antioxidant properties of pre-cut celery (Apium graveolens L.). Intl. J. Food Sci. Technol. 43:44-51.

Yemenicioğlu, A., M. Özkan, and B. Cemeroğlu. 1997. Heat inactivation kinetics of apple polyphenoloxidase and activation of its latent form. J. Food Sci. 62:508-510. 